Thabiea : Journal of Natural Science Teaching
Vol. 4 (1), hlm. 82-95, 2021
Available online at
http://journal.iainkudus.ac.id/index.php/Thabiea
p-issn: 2580-8474, e-issn: 2655-898X

\title{
The Effect of Conceptual Change Using The Adobe Quran on Misconception, Self-Regulation, Self-Efficacy, and Self-Confidence
}

\author{
Nukhbatul Bidayati Haka ${ }^{1 *}$, Anindea Nurrurohmah ${ }^{2}$, Desty Wulansari ${ }^{3}$, Mai Sari ${ }^{4}$ \\ 1,2,3,4 Raden Intan State Islamic University Lampung, Jln. Col. Endro Suratmin, Bandar \\ Lampung, 46461, Indonesia \\ * Korespondensi: nukhbatulbidayatihaka@radenintan.ac.id
}

\begin{tabular}{|c|c|}
\hline & Abstract \\
\hline $\begin{array}{l}\text { Keywords: } \\
\text { Conceptual Change, } \\
\text { Misconception, } \\
\text { Self-Regulation, } \\
\text { Self-Efficacy, } \\
\text { Self-Confidence }\end{array}$ & $\begin{array}{l}\text { This study aims to (1) determine the effect of conceptual change using the adobe Quran } \\
\text { on the reduction of misconceptions, (2) determine the effect of conceptual change using } \\
\text { the adobe Quran on self-regulation, self-efficacy, and self-confidence. The population } \\
\text { in this study were all students of class XI in } 3 \text { schools. At Islamic Senior High School } 1 \\
\text { Bandar Lampung and Senior High School } 1 \text { Negara Batin with a total of } 6 \text { classes with } \\
\text { a total of } 95 \text { and } 87 \text { students respectively. Senior High School } 2 \text { Sekampung with a total } \\
\text { of } 4 \text { classes and a total of } 70 \text { students. This study used a weak experiment with a one- } \\
\text { group pretest-posttest design. So that there are } 3 \text { classes as research classes namely, } \\
\text { class XI MIA 1, XI MIA 2, and XI MIA } 6 \text { at Islamic Senior High School } 1 \text { Bandar } \\
\text { Lampung, class XI MIA 1, XI MIA } 2 \text {, and XI MIA } 3 \text { at Senior High School } 2 \\
\text { Sekampung and Senior High School } 1 \text { Negara Batin. The data in this study were } \\
\text { obtained through a misconception test accompanied by CRI (Certainty of Response } \\
\text { Index) and self-regulation, self-efficacy, and self-confidence questionnaire. Data were } \\
\text { analyzed using a one-sample t-test. This study concludes that the conceptual change } \\
\text { model using the adobe Quran can reduce misconception and increase self-regulation, } \\
\text { self-efficacy, and self-confidence. The researcher suggests applying the conceptual } \\
\text { change model using adobe Quran to other learning materials so that it can help in } \\
\text { reducing misconceptions in other learning materials. }\end{array}$ \\
\hline
\end{tabular}

To cite this article:

Haka, NB, Nururrohmah, A. (2021). The Effect of Conceptual Change Using The Adobe Quran on Misconception, Self-Regulation, Self-Efficacy, Self-Confidence. Thabiea : Journal of Natural Science Teaching, Vol. 4 (1), hlm. 82-95, 2021.

\section{Introduction}

Learning science is one of the areas of learning that is closely related to concepts. According to Sagala (2012), conception is the product of a person's or group of people manifested in the form of a definition that will produce knowledge that includes principles, laws, and theories. According to Ormrod (2009), concepts are groupings of events that have a connection to a particular matter. According to Hamalik (2012), the concept is a category that has some common characteristics. Understanding the concept is very important for students because conception is the basis of thinking. According to Berg (2004), each individual will have a different understanding of it, and therefore among the individuals will also have differences. However, if the wrong conception is used as a primary basis for understanding concepts, that is a misconception.

The misconception is a conception that doesn't fit the concept of the experts (A'yun, 2018). They are the principal cause of the obstructions process of receiving and assimilating 
new knowledge to students (Suparno, 2005). So that prevents students from being successful in understanding knowledge. If misconception isn't eliminated immediately, it will result in continual misunderstandings and will remain that way (Irawati, 2019). The reproductive system is one of the biological materials that contains a mistake in the concept (Dini et al., 2018). According to Ardiyanti and Rahmawati Utami in their research, it stated that in several subconcepts of the reproductive system material have misconceptions, including sub-concepts menstruation, gamete cell formation, fertility, pregnancy, childbirth, breastfeeding, and ovulation. Apart from being influenced by student's initial conceptions, misconceptions can also be affected by emotional aspects such as self-regulation, self-efficacy, and self-confidence (Ardiyanti \& Rahmawati Utami, 2018).

Self-regulation is as significant as the adjustment process and mental stability treatment, the ability to self-regulate (Anggoro \& Haka, 2019). Self-regulation can be measured when a person controls and direct his action well (Haka et al., 2020). According to Robert J Marzano (1994), a person with a balanced mind will have calm self-confidence and a good personality. Self-regulation has several indicators, that is, (1) plan effective (planning), (2) construct and use sources of information (resources), and (3) sensitivity to give feedback.

Besides self-regulation, there is another emotional aspect that is self-efficacy. Selfefficacy is a person's belief in his or her ability to achieve the purpose (Bandura, 1986). Selfefficacy is self-concept in someone that can help direct someone to continue to believe in their ability to reach their every wish (Utami et al., 2020). Individuals who have high self-efficacy are the ones who have a stronger soul and do not give up easily in achieving their desires. According to Bandura (1986), self-efficacy consists of three dimensions, that is, (1) a level or magnitude dimension, (2) a generality dimension, and (3) a strength dimension.

Another emotional aspect other than self-regulation and self-efficacy that can affect misconception is self-confidence. Self-confidence is a significant personality aspect in a person. Without self-confidence, of course, it will cause many problems in one's life. Self-confidence can become impacted by the abilities and skills a person has (Syam, 2017). Dini, Wijaya, and Suganda in their research stated that the higher a person's self-confidence in their abilities, the greater their enthusiasm for completing their work (Dini et al., 2018). Good self-confidence will make students successful in studying Biology because, with this self-confidence, students will struggle to achieve achievements. So that students will succeed in learning Biology (Fitriani, 2015). Self-confidence has five indicators, namely (1) confidence in one's abilities, (2) optimism, (3) objective, (4) responsibility, (5) rational.

The use of appropriate learning models can help reduce misconceptions and improve self-regulation, self-efficacy, and self-confidence. Khoiriyah in her research suggests that conceptual change models can help reduce mistakes in the student's concept because this learning model asks students to confront prejudices against themselves and bring a change in them (Khoiriyah, 2017). According to Rapih and Sutaryanto, conceptual change models provide opportunities for students to engage directly in the learning process. Helping students understand the correct concepts so that they can help reduce misconceptions. It can create a more active learning environment. Allowing students the opportunity to discover for themselves the knowledge they learned so that creating meaningful learning, and can boost teacher creativity (Rapih \& Sutaryanto, 2017). 
Conceptual change has six compositions, including (1) the presentation of conceptual and contextual problems. (2) the confrontation of misconception matters. (3) the opposition of confrontation with a demonstration of strategies, analogies, and opposing examples. (4) the scientific evidence of concepts and principles. (5) the material presented and contextual sample. (6) confirmation through questions to expand meaningful meaning and application of knowledge (Pebriyanti \& Sahidu, 2015).

The research is conducted for 4 weeks. This research needs to be conducted because misconception cannot be ignored and cannot be considered simple, for if misconception is not immediately reduced it will be resistant. So a proper learning model is needed to assist in reducing misconception and can improve self-regulation, self-efficacy, and self-confidence. Based on this, the aim of this research is (1) knowing the effect of conceptual change using the android Quran on the reduction of misconceptions (2) knowing the effect of conceptual change using the android Quran on self-regulation, self-efficacy, and self-confidence.

\section{Method}

This research is quantitative using the one-group pretest-posttest design. This design was used because the researchers didn't use the control class so that the 3 classes were a research class and a conceptual change model using the adobe Quran was applied to 3 classes. The pattern of the one-group pretest-posttest design in figure 1 .

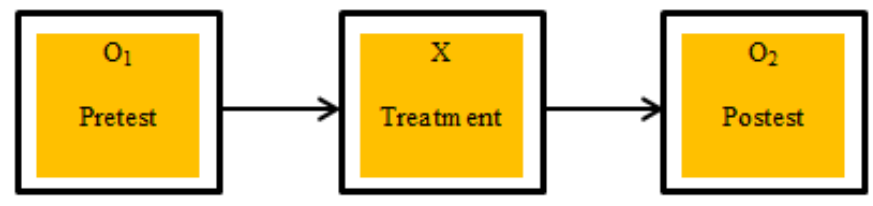

Figure 1. The One Group Pretest-Postest Design Pattern (Frankel, R. Jack \& Norman, E. Wallen, 2009)

The research is a weak experiment and implemented in three schools in Lampung province. Namely, Islamic Senior High School 1 Bandar Lampung is located in Sukarame, Bandar Lampung. Senior High School 2 Sekampung is located in Sekampung, East Lampung, and Senior High School 1 Negara Batin is located in Negara Batin, Way Kanan. The sample in this research is accepted using random cluster sampling (Sumaryanto \& Lestari, 2015). The population was taken from Islamic Senior High School 1 Bandar Lampung namely, XI MIA 1, XI MIA 2, XI MIA 6 with a total of 95 students, while for Senior High School 2 Sekampung and Senior High School 1 Negara Batin namely, class XI MIA 1, XI MIA 2, and XI MIA 3 with a total of 70 students and 87 students.

The data collection technique in this research was obtained through the misconception test accompanied by a CRI (Certainty of Response Index) and the questionnaire of selfregulation, self-efficacy, and self-confidence. The data obtained later in analysis using the normality test, the homogeneity test, and the hypothesis test using a one-sample t-test. The hypothesis in this study used a one-sample t-test. The first hypothesis in this research is $\mathrm{H} 0$ : There is no effect of conceptual changes using the adobe Quran on reducing misconceptions. H1: there is an effect of conceptual change using the adobe Quran on reduced misconceptions. 
The second hypothesis is H0: there is no effect of conceptual changes using the adobe Quran on self-regulation, self-efficacy, and self-confidence. H1: there is an effect of conceptual changes from using the adobe Quran on self-regulation, self-efficacy, and self-confidence. With the hypothesis testing criteria if sig. $\leq 0.05 \mathrm{H} 0$ rejected, $\mathrm{H} 1$ is accepted.

\section{Results and Discussion}

\section{Misconceptions}

Misconceptions were obtainable from filling in multiple-choice questions about the reproductive system accompanied by a CRI (Certainty of Response Index) at the beginning and the end of the lesson (Ramadhan et al., 2020). The concept mastery test in Table 1, Table 2, and Table 3 show that the misconceptions are reduced at three schools. At Islamic Senior High School 1 Bandar Lampung, misconceptions experience a reduction by 6\%. While in Senior High School 2 Sekampung, there is a reduction by 9\%, and Senior High School 1 Negara Batin is reduced by $1 \%$.

Table 1. The Results Of Concept Mastery Test At Islamic Senior High School 1 Bandar Lampung

\begin{tabular}{|c|c|c|c|c|c|c|c|}
\hline \multirow[b]{3}{*}{ No } & \multirow[b]{3}{*}{ Class } & \multicolumn{6}{|c|}{ Percentage } \\
\hline & & \multicolumn{3}{|c|}{ Pretest } & \multicolumn{3}{|c|}{ Postest } \\
\hline & & $\begin{array}{c}\text { Know } \\
\text { The } \\
\text { Concep } \\
\text { t }\end{array}$ & $\begin{array}{c}\text { Misconceptio } \\
\mathbf{n}\end{array}$ & $\begin{array}{l}\text { Didn't } \\
\text { Know } \\
\text { The } \\
\text { Concept }\end{array}$ & $\begin{array}{c}\text { Know } \\
\text { The } \\
\text { Concept }\end{array}$ & $\begin{array}{c}\text { Misconceptio } \\
\text { n }\end{array}$ & $\begin{array}{c}\text { Didn't } \\
\text { Know The } \\
\text { Concept }\end{array}$ \\
\hline 1 & XI MIA 1 & $47 \%$ & $48 \%$ & $5 \%$ & $56 \%$ & $41 \%$ & $4 \%$ \\
\hline 2 & XI MIA 2 & $47 \%$ & $48 \%$ & $6 \%$ & $54 \%$ & $41 \%$ & $4 \%$ \\
\hline 3 & XI MIA 6 & $48 \%$ & $49 \%$ & $3 \%$ & $55 \%$ & $43 \%$ & $3 \%$ \\
\hline \multicolumn{2}{|c|}{ Average } & $47 \%$ & $48 \%$ & $5 \%$ & $55 \%$ & $42 \%$ & $4 \%$ \\
\hline
\end{tabular}

Table 2. The Results Of Concept Mastery Test At Senior High School 2 Sekampung

\begin{tabular}{cccccccc}
\hline & & \multicolumn{5}{c}{ Percentage } \\
\cline { 3 - 7 } No & Class & $\begin{array}{c}\text { Know } \\
\text { The } \\
\text { Concept }\end{array}$ & Misconception & $\begin{array}{c}\text { Didn't } \\
\text { Know } \\
\text { The } \\
\text { Concept }\end{array}$ & $\begin{array}{c}\text { Know } \\
\text { The } \\
\text { Concept }\end{array}$ & Misconception & $\begin{array}{c}\text { Didn't } \\
\text { Know The } \\
\text { Concept }\end{array}$ \\
\hline 1 & XI MIA 1 & $40 \%$ & $36 \%$ & $24 \%$ & $53 \%$ & $26 \%$ & $21 \%$ \\
\hline 2 & XI MIA 2 & $43 \%$ & $45 \%$ & $12 \%$ & $49 \%$ & $40 \%$ & $10 \%$ \\
\hline 3 & XI MIA 3 & $38 \%$ & $46 \%$ & $16 \%$ & $49 \%$ & $32 \%$ & $20 \%$ \\
\hline \multicolumn{2}{c}{ Average } & $\mathbf{4 0 \%}$ & $\mathbf{4 2 \%}$ & $\mathbf{1 7 \%}$ & $\mathbf{5 0 \%}$ & $\mathbf{3 3 \%}$ & $\mathbf{1 7 \%}$ \\
\hline
\end{tabular}


Table 3. The Results Of Concept Mastery Test At Senior High School 1 Negara Batin

\begin{tabular}{cccccccc}
\hline & & \multicolumn{5}{c}{ Percentage } \\
\cline { 3 - 8 } No & Class & $\begin{array}{c}\text { Know } \\
\text { The } \\
\text { Concept }\end{array}$ & Misconception & $\begin{array}{c}\text { Didn't } \\
\text { Know } \\
\text { The } \\
\text { Concept }\end{array}$ & $\begin{array}{c}\text { Know } \\
\text { The } \\
\text { Concept }\end{array}$ & Misconception & $\begin{array}{c}\text { Didn't } \\
\text { Know The } \\
\text { Concept }\end{array}$ \\
\hline 1 & XI MIA 1 & $64 \%$ & $20 \%$ & $16 \%$ & $63 \%$ & $19 \%$ & $17 \%$ \\
\hline 2 & XI MIA 2 & $64 \%$ & $20 \%$ & $15 \%$ & $67 \%$ & $19 \%$ & $14 \%$ \\
\hline 3 & XI MIA 3 & $63 \%$ & $21 \%$ & $16 \%$ & $66 \%$ & $18 \%$ & $16 \%$ \\
\hline \multicolumn{2}{c}{ Average } & $\mathbf{6 4 \%}$ & $\mathbf{2 0 \%}$ & $\mathbf{1 6 \%}$ & $\mathbf{6 5 \%}$ & $\mathbf{1 9 \%}$ & $\mathbf{1 6 \%}$ \\
\hline
\end{tabular}

\section{Questionnaire}

The questionnaire self-regulation, self-efficacy, and self-confidence were taken using the Linkert scale at the beginning and the end of the lesson (Ridwan, 2014). The Linkert scale scoring table can be seen in Table 4 and Table 5. The data from the questionnaire is selfregulation shown in Table 6 . The questionnaire data is self-efficacy shown in Table 7, and the questionnaire data from self-confidence shown in Table 8.

Table 4. Linkert Scale Rating Score

\begin{tabular}{c|c|c|c}
\hline Positive Statment & Score & Negative Statment & Score \\
\hline Very Often & 4 & Very Often & 1 \\
\hline Often & 3 & Often & 2 \\
\hline Rarely & 2 & Rarely & 3 \\
\hline Never & 1 & Never & 4 \\
\hline
\end{tabular}

Table 5. Category

\begin{tabular}{c|c}
\hline Range & Category \\
\hline $81 \%<\mathrm{SR}, \mathrm{SE}, \mathrm{SC} \leq 100 \%$ & Very High \\
\hline $61 \%<\mathrm{SR}, \mathrm{SE}, \mathrm{SC} \leq 80 \%$ & High \\
\hline $41 \%<\mathrm{SR}, \mathrm{SE}, \mathrm{SC} \leq 60 \%$ & Enough \\
\hline $21 \%<\mathrm{SR}, \mathrm{SE}, \mathrm{SC} \leq 40 \%$ & Low \\
\hline SR,SE,SC $\leq 20 \%$ & Very Low \\
\hline
\end{tabular}

Table 6. The Results Of The Self-Regulation Questionnaire at Islamic Senior High School 1 Bandar Lampung

\begin{tabular}{|c|c|c|c|c|c|c|c|}
\hline \multirow{3}{*}{ No } & \multirow{3}{*}{ Class } & \multicolumn{6}{|c|}{ Percentage } \\
\hline & & \multicolumn{3}{|c|}{ Pretest } & \multicolumn{3}{|c|}{ Postest } \\
\hline & & Planning & Resources & Feedback & Planning & Resources & Feedback \\
\hline 1 & XI MIA 1 & $67 \%$ & $67 \%$ & $70 \%$ & $69 \%$ & $68 \%$ & $71 \%$ \\
\hline 2 & XI MIA 2 & $65 \%$ & $68 \%$ & $70 \%$ & $70 \%$ & $69 \%$ & $67 \%$ \\
\hline \multirow[t]{2}{*}{3} & XI MIA 6 & $69 \%$ & $68 \%$ & $66 \%$ & $72 \%$ & $69 \%$ & $66 \%$ \\
\hline & Average & $67 \%$ & $68 \%$ & $67 \%$ & $70 \%$ & $69 \%$ & $68 \%$ \\
\hline \multirow{2}{*}{\multicolumn{2}{|c|}{ Self-Regulation }} & & $67 \%$ & & & $69 \%$ & \\
\hline & & & High & & & High & \\
\hline
\end{tabular}


Table 7. The Results Of The Self-Efficacy Questionnaire at Senior High School 2 Sekampung

\begin{tabular}{|c|c|c|c|c|c|c|c|}
\hline \multirow{3}{*}{ No } & \multirow{3}{*}{ Class } & \multicolumn{6}{|c|}{ Percentage } \\
\hline & & \multicolumn{3}{|c|}{ Pretest } & \multicolumn{3}{|c|}{ Postest } \\
\hline & & Magnitude & Strenght & Generality & Magnitude & Strenght & Generality \\
\hline 1 & XI MIA 1 & $55 \%$ & $49 \%$ & $60 \%$ & $64 \%$ & $61 \%$ & $68 \%$ \\
\hline 2 & XI MIA 2 & $59 \%$ & $58 \%$ & $58 \%$ & $66 \%$ & $58 \%$ & $66 \%$ \\
\hline 3 & XI MIA 3 & $60 \%$ & $50 \%$ & $51 \%$ & $61 \%$ & $59 \%$ & $79 \%$ \\
\hline & verage & $58 \%$ & $52 \%$ & $56 \%$ & $64 \%$ & $59 \%$ & $71 \%$ \\
\hline \multirow{2}{*}{\multicolumn{2}{|c|}{ Self-Efficacy }} & & $55 \%$ & & & $65 \%$ & \\
\hline & & & Enough & & & High & \\
\hline
\end{tabular}

Table 8. The Results Of The Self-Efficacy Questionnaire at Senior High School 1

\begin{tabular}{cccccc}
\multicolumn{7}{c}{ Negara Batin } \\
\hline \multirow{2}{*}{ No } & \multirow{2}{*}{ Indicator } & \multicolumn{2}{c}{ Pretest } & \multicolumn{2}{c}{ Postest } \\
\cline { 2 - 6 } & Persentage & Information & Persentage & Information \\
\hline $\mathbf{1}$ & $\begin{array}{c}\text { Confidence in one's } \\
\text { abilities }\end{array}$ & $62 \%$ & High & $70 \%$ & High \\
\hline $\mathbf{2}$ & Optimistic & $65 \%$ & High & $79 \%$ & High \\
\hline $\mathbf{3}$ & Objective & $63 \%$ & High & $74 \%$ & High \\
\hline $\mathbf{4}$ & Responsible & $65 \%$ & High & $76 \%$ & High \\
\hline $\mathbf{5}$ & Rational & $64 \%$ & High & $75 \%$ & High \\
\hline
\end{tabular}

The Questionnaire results for self-regulation, self-efficacy, and self-confidence indicated a percentage increase at three schools before and after learning. Selfregulation increased by $2 \%$, while self-efficacy increased by $10 \%$. And each indicator of selfconfidence increased, for the indicator confidence in ability increased by $8 \%$, the optimistic indicators increased by $14 \%$, and. The objective, responsible, and rational indicators increased by $11 \%$.

\section{The Results of Hypothesis Test Analysis of One-Sample T-Test}

The recapitulating of concept mastery and self-regulation, self-efficacy, and selfconfidence were analyzed using the one-sample t-test analysis technique. Normality test using the Kolmogorov Smirnov test. If normal distribution data can continue to the one-sample t-test. The normality table for misconceptions in Table 9 and questionnaires in Table 10. The onesample t-test hypothesis proposed is as follows.

$\mathrm{H} 0$ : accepted if the value is sig. $\geq \alpha(0.05)$, then $\mathrm{H} 1$ is rejected.

$\mathrm{H} 1$ : accepted if the value is sig. $\leq \alpha(0.05)$, then $\mathrm{H} 0$ is rejected.

Based on Table 11, the results of the one-sample t-test misconceptions, and Table 12, the one-sample t-test questionnaire results for self-regulation, self-efficacy, and selfconfidence, all three schools received sig. (2-tailed) $\leq 0.05$, then $\mathrm{H} 1$ is accepted. 
Table 9. Normality Test Of Misconception

\begin{tabular}{cccc}
\hline Test Type & $\begin{array}{c}\text { Asymp. Sig 2 } \\
\text { Tailed }\end{array}$ & $\begin{array}{c}\text { Table Significance } \\
\text { Value Criteria }(\mathbf{0 , 0 5})\end{array}$ & $\begin{array}{c}\text { Conclusion (Sig count }>\mathbf{1} / \mathbf{2} \\
(\boldsymbol{\alpha})(\mathbf{0 , 0 2 5})=\text { normal } \\
\text { distribution) }\end{array}$ \\
\hline Pretest & 0,06 & 0,05 & Normal Distribution \\
\hline Posttest & 0,07 & 0,05 & Normal Distribution \\
\hline
\end{tabular}

Table 10. Normality Test Of Questionnaire

\begin{tabular}{|c|c|c|c|c|}
\hline Quesionnaire & Test Type & $\begin{array}{c}\text { Asymp. Sig } 2 \\
\text { Tailed }\end{array}$ & $\begin{array}{c}\text { Table Significance } \\
\text { Value Criteria } \\
(\mathbf{0 , 0 5})\end{array}$ & $\begin{array}{c}\text { Conclusion }(\text { Sig } \\
\text { count }>1 / 2(\alpha) \\
(0,025)=\text { normal } \\
\text { distribution }) \\
\end{array}$ \\
\hline \multirow{2}{*}{ Self-Regulation } & Pretest & 0,559 & 0,05 & Normal Distribution \\
\hline & Posttest & 0,427 & 0,05 & Normal Distribution \\
\hline \multirow{2}{*}{ Self-Efficacy } & Pretest & 0,200 & 0,05 & Normal Distribution \\
\hline & Posttest & 0,200 & 0,05 & Normal Distribution \\
\hline \multirow{2}{*}{ Self-Confidance } & Pretest & 0,042 & 0,05 & Normal Distribution \\
\hline & Posttest & 0,042 & 0,05 & Normal Distribution \\
\hline
\end{tabular}

Table 11. The Results of One-Sample T-Test Misconceptions

\begin{tabular}{|c|c|c|c|c|c|c|}
\hline The Name Of Schools & Tes & $\begin{array}{c}\text { Test } \\
\text { Value }\end{array}$ & $\mathbf{t}$ & df & $\begin{array}{c}\text { Sig. } \\
(2- \\
\text { tailed) }\end{array}$ & Information \\
\hline \multirow{2}{*}{$\begin{array}{c}\text { Islamic Senior High School } \\
1 \text { Bandar Lampung }\end{array}$} & Pretes & \multirow{2}{*}{0.70} & -7.420 & 74 & 0,000 & \multirow{2}{*}{$\begin{array}{c}\text { Sig. }(2 \text {-tailed }) \leq \alpha \\
(0,05)\end{array}$} \\
\hline & Postes & & -22.709 & 74 & 0,000 & \\
\hline \multirow{2}{*}{$\begin{array}{c}\text { Senior High School } 2 \\
\text { Sekampung }\end{array}$} & Pretes & \multirow{2}{*}{0.70} & 35,787 & 69 & 0,000 & \multirow{2}{*}{$\begin{array}{c}\text { Sig. }(2 \text {-tailed }) \leq \alpha \\
(0,05)\end{array}$} \\
\hline & Postes & & 44,158 & 69 & 0,000 & \\
\hline \multirow{2}{*}{$\begin{array}{c}\text { Senior High School } 1 \\
\text { Negara Batin }\end{array}$} & Pretes & \multirow{2}{*}{0.70} & -22.544 & 74 & 0,000 & \multirow{2}{*}{$\begin{array}{c}\text { Sig. }(2 \text {-tailed }) \leq \alpha \\
(0,05)\end{array}$} \\
\hline & Postes & & -22.467 & 74 & 0,000 & \\
\hline
\end{tabular}

Table 12. The Results of One-Sample T-Test Questionnaire

\begin{tabular}{|c|c|c|c|c|c|c|}
\hline Questionnaire & Tes & Value & $\mathbf{t}$ & df & $\begin{array}{l}\text { Sig. (2- } \\
\text { tailed) }\end{array}$ & Information \\
\hline \multirow{2}{*}{ Self-Regulation } & Pretes & 60 & -11.198 & 94 & 0,000 & \multirow[b]{2}{*}{ Sig. $(2$-tailed $) \leq \alpha(0,05)$} \\
\hline & Postes & 60 & -9.553 & 94 & 0,000 & \\
\hline \multirow{2}{*}{ Self-Efficacy } & Pretes & 60 & -7.006 & 69 & 0,000 & \multirow{2}{*}{ Sig. $(2$-tailed $) \leq \alpha(0,05)$} \\
\hline & Postes & 60 & 12.036 & 69 & 0,000 & \\
\hline \multirow{2}{*}{ Self-Confidence } & Pretes & 70 & -15.986 & 86 & 0,000 & \multirow{2}{*}{ Sig. $(2$-tailed $) \leq \alpha(0,05)$} \\
\hline & Postes & 70 & -15.558 & 86 & 0,000 & \\
\hline
\end{tabular}

The Results in Table 1, Table 2, and Table 3 show that using conceptual change with the adobe Quran can reduce misconceptions on learning. Senior High School 2 Sekampung (Table 2) experienced a significant decrease in misconceptions compared to Islamic Senior High School 1 Bandar Lampung (Table 1) and Senior High School 1 Negara Batin (Table 3). The hypothesis one sample t-test shows that conceptual changes can help reduce misconceptions in students with sig. (2-tailed) $0.000 \leq 0.05$ (Table 11). 
According to Ramadhani in his research, she stated that the reproductive system is one of the biology learning concepts that requires considerable understanding. The reduction of misconception discernible from the percentage of misconception reduction achieved at each question indicator at the beginning and end of learning. The materials of the reproductive system matter are those regarding the function structure of the reproductive organs. Explains the process of forming sex cells (gametogenesis). Link the ovulation process to the menstrual cycle. Analyze the process of fertilization, gestation, and childbirth. Conclude abnormalities and diseases in the reproductive system, and gather information on hormones that affect the reproductive system (Ramadhani, 2016). The percentage reduction of each indicator of the misconception question among the three schools shown in Figure 2, Figure 3, and Figure 4.

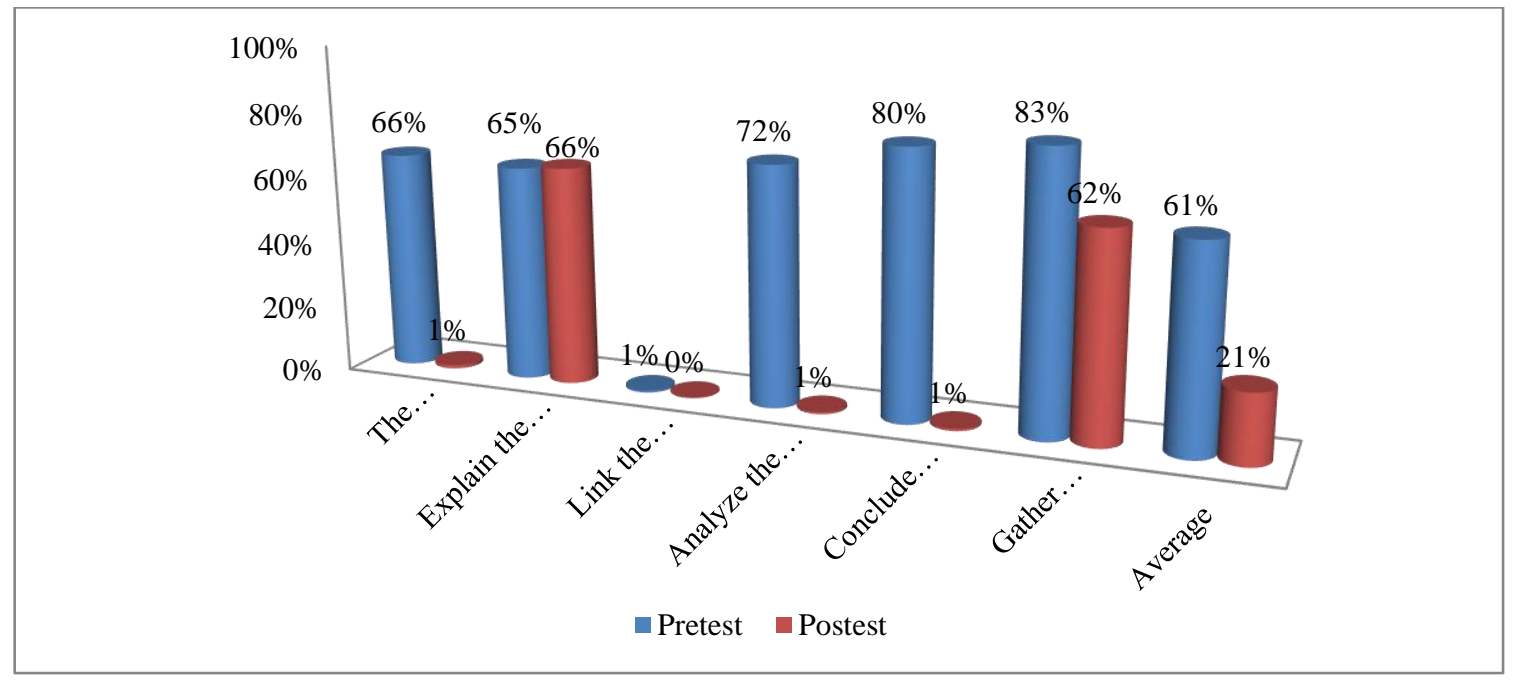

Figure 2. Percentage reduction of misconception for each indicator in Islamic Senior High School 1 Bandar Lampung

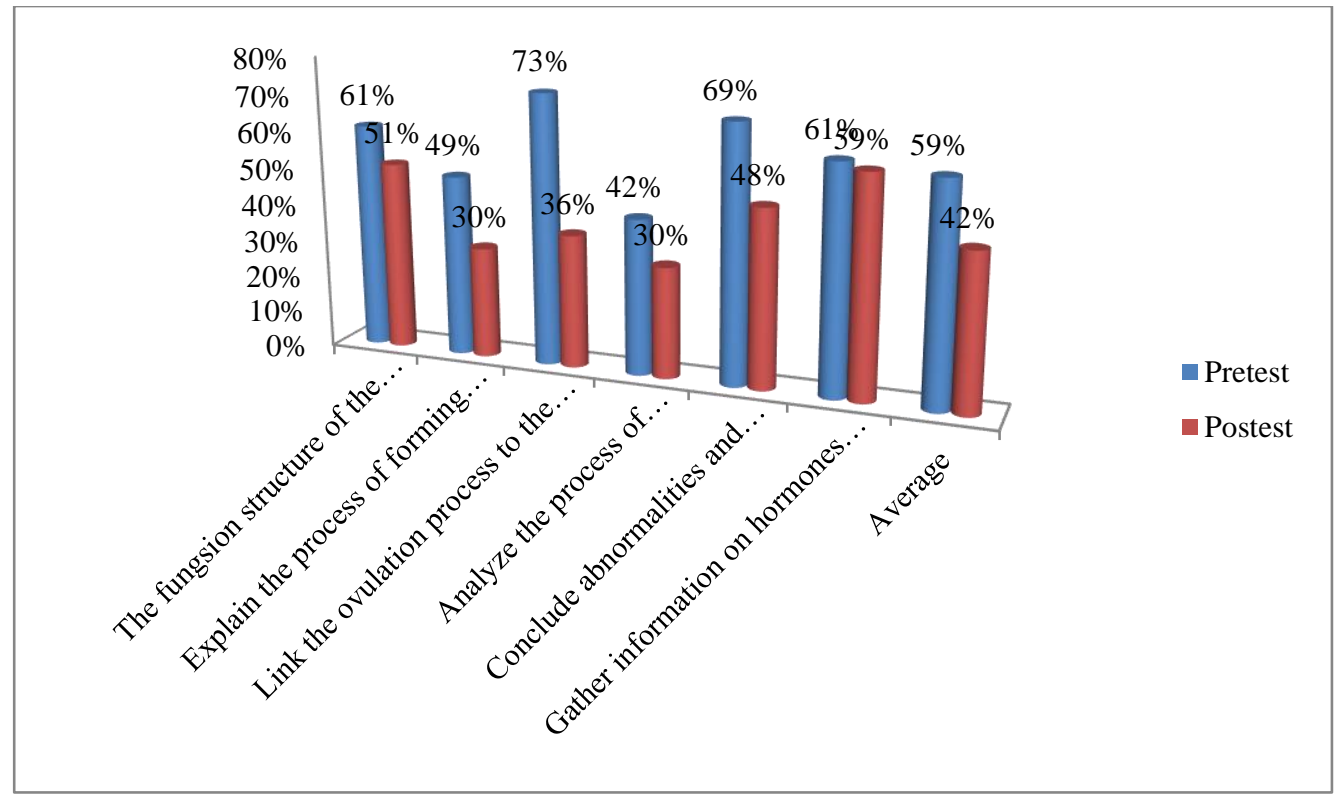

Figure 3. Percentage reduction of misconception for each indicator in Senior High School 2 Sekampung 


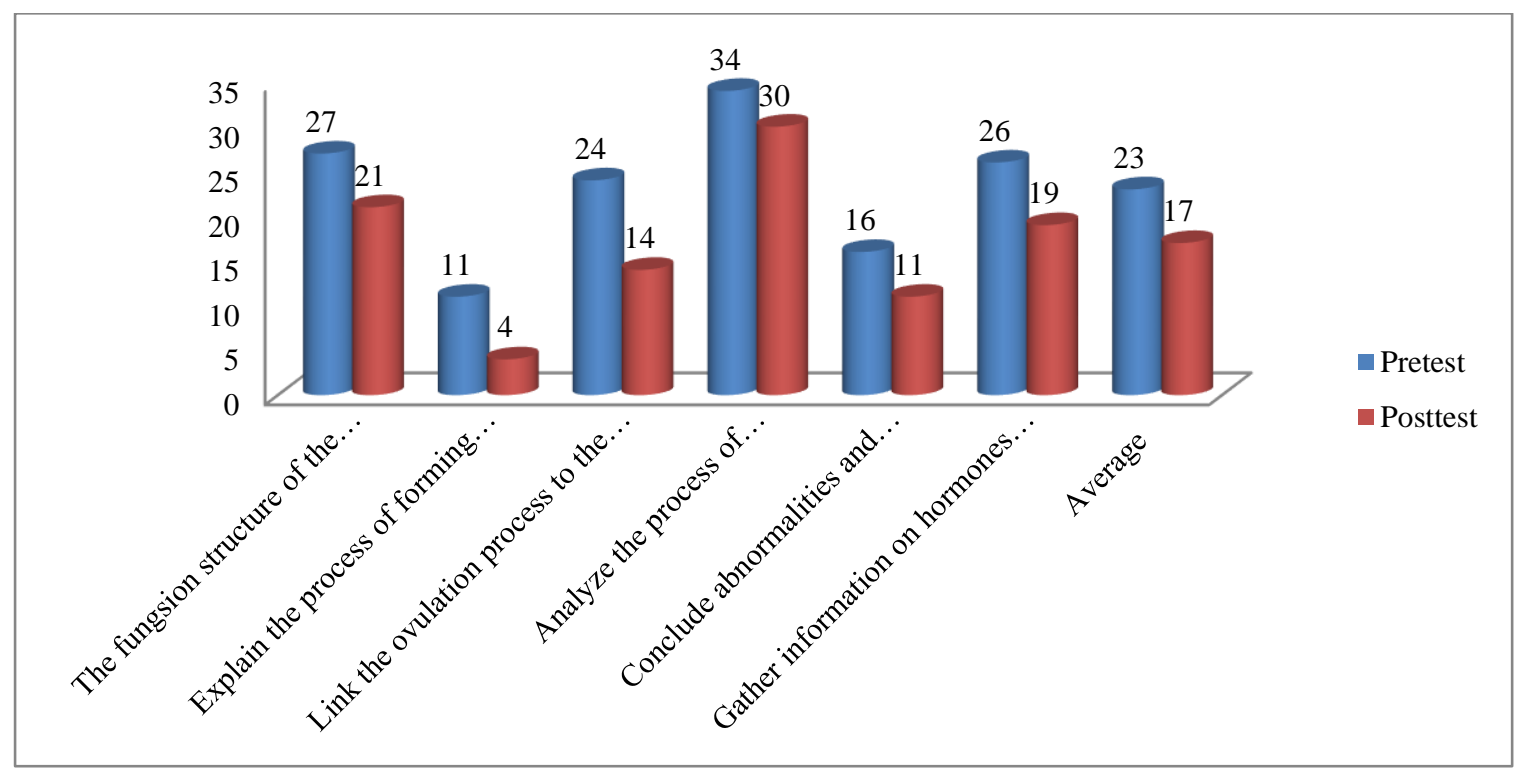

Figure 4. Percentage reduction of misconception for each indicator in Senior High School 1 Negara Batin

Based on Figures 2, 3, and 4, shows that the misconceptions of students in three schools, namely Islamic Senior High School 1 Bandar Lampung (Figure 2), Senior High School 2 Sekampung (Figure 3), and Senior High School 1 Negara Batin (Figure 4) on each indicator item decreased after using conceptual changes. Because a conceptual change model can cause conflict in students where student's knowledge is contrary to new knowledge and can help students correct that false knowledge (Rachmawati \& Supardi, 2021). It agrees with Santyasa (2007) that the conceptual change model can help learners change through the concept change process students take before learning.

The learning process uses conceptual change through several stages, the presence of conceptual and contextual problems, confrontation of misconceptions related matters, the opposition of confrontation with a demonstration of strategies, analogies, and opposing examples, scientific evidence of concepts and principles, the existence of contextual materials and samples, and confirmation through questions to expand meaningful meaning and application of knowledge (Rizaldi et al., 2019). At the first stage, the presentation of conceptual and contextual problems. The teacher gave an example of the problem with the reproductive system matter in daily life. Students give his or her opinion on their knowledge so that the process of assimilation can occur. Hidayatullah in his research states that through assimilation, students will use this initial knowledge to deal with new concepts. This activity shows that there has been a cognitive conflict in students (Hidayatullah et al., 2020).

At the confrontation stage of misconceptions-related matters, the teacher provided examples on the LKPD sheet. Students answer the questions on the LKPD sheet using the knowledge they have. The students answer the LKPD by conducting group discussions, looking for answers via the internet or biology textbooks. In this activity, students are not allowed to use the adobe Quran. If they do, they will copy the answer from the adobe Quran to the LKPD. In the phase of the opposition of confrontation demonstration of strategies, analogies, and examples against which students are faced with the accommodation phase, conceptual change 
occurs when the knowledge possessed by the student conflicts with new learning. According to Makhrus, Nur, and Widodo, their states that when "student knowledge contradicts new knowledge, it will cause conflict which helps students to fix what they believe so can be correcting that false belief with existing evidence."(Makhrus et al., 2014)

At the stage of proving scientific concepts and principles and presenting contextual material and examples, the teacher provides the adobe Quran to help students understand the correct conceptions. At this stage, the teacher gives a material proven using the adobe Quran. In the syntax of confirmation through questions to expand meaningful meaning and application knowledge. The teacher asks students to connect each concept from the beginning to the end of the learning.

The misconception is not only caused by a student's initial conception before school learning activities and may occur because of some other aspects such as self-regulation, selfefficacy, and self-confidence. Islamic Senior High School 1 Bandar Lampung (Table 6) and Senior High School 1 Negara Batin (Table 8) have high self-regulation and selfconfidence before studying, while in Senior High School 2 Sekampung (Table 7), they have sufficient self-efficacy before studying. Madrasah Aliyah 1 Bandar Lampung and Senior High School 1 Negara Batin experienced a slight increase in the percentage of selfregulation and self-confidence, while Senior High School 2 Sekampung experienced a higher percentage increase. Based on the hypotheses using the one-sample t-test suggests that conceptual changes are effective in raising self-regulation, self-efficacy, and self-confidence with sig (2-tailed) values of $0.000 \leq 0.05$ (Table 12).

The result of self-regulation, self-efficacy, and self-confidence at the current three schools at table 6 , table 7 , and table 8 indicates that while students have high emotional aspects, it isn't a guarantee that students don't experience misconceptions. They can significantly affect misconception reduction. So with the help of conceptual change models using the adobe Quran, students can maintain and enhance those emotional aspects and reducing misconception. Students were given a questionnaire at the beginning and end of the lesson. The questionnaire used adjusted to the material of the reproductive system.

Self-regulation, self-efficacy, and self-confidence increased in the three different schools can be seen in detail in the percentages of each indicator on the questionnaire. The index of self-regulation is plan effective (planning), wake up and use sources of information (resources), and sensitivity to giving feedback (Robert J Marzano, 1994). Self-efficacy, there are three dimensions of level or magnitude, a generality dimension, and strength dimension (Bandura, 1986). The indicator of self-confidence is confidence in one's abilities, optimism, objectivity, responsibility, and rationality (Fitriani, 2015). The percentages of aspects of influence from the three schools for each indicator shown in Figure 5. self-regulation, Figure 6. self-efficacy, and Figure 7. self-confidence.

Figure 5, Figure 6, and Figure 7 show an increase in each indicator. Each indicator increases this because, at the time, the student's learning process applies a conceptual change using the adobe Quran very well. 


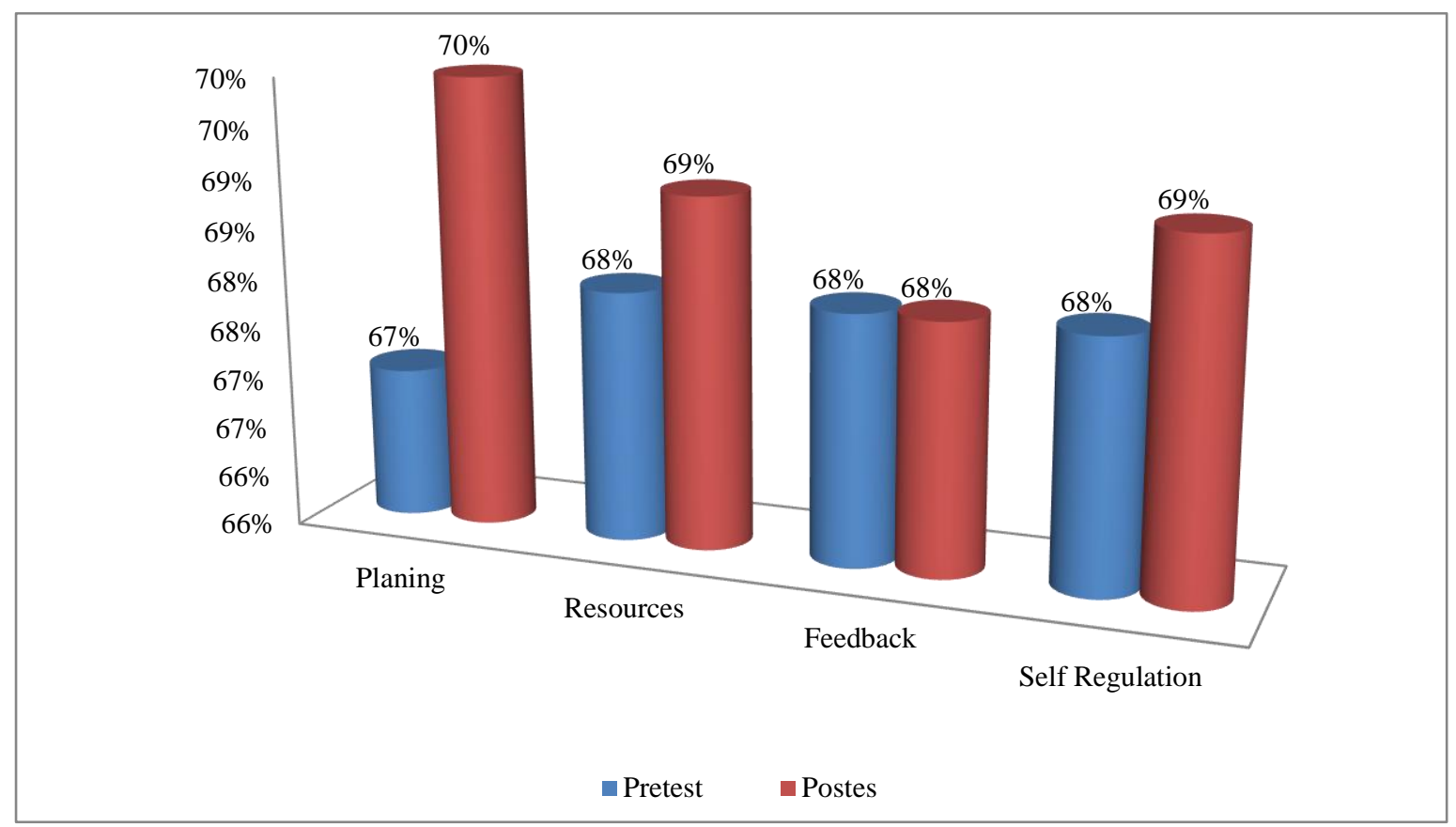

Figure 5. Percentage of Self-Regulation in Islamic Senior High School 1 Bandar Lampung

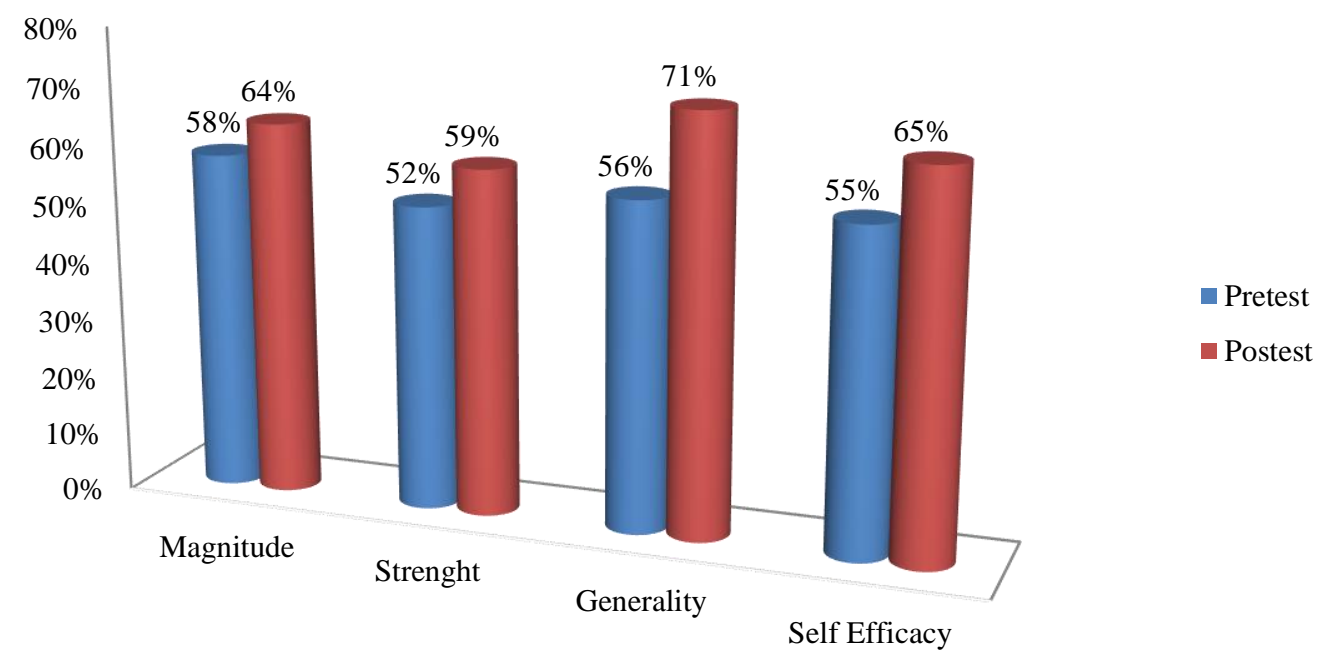

Figure 6. Percentage of Self-Efficacy in Senior High School 2 Sekampung 


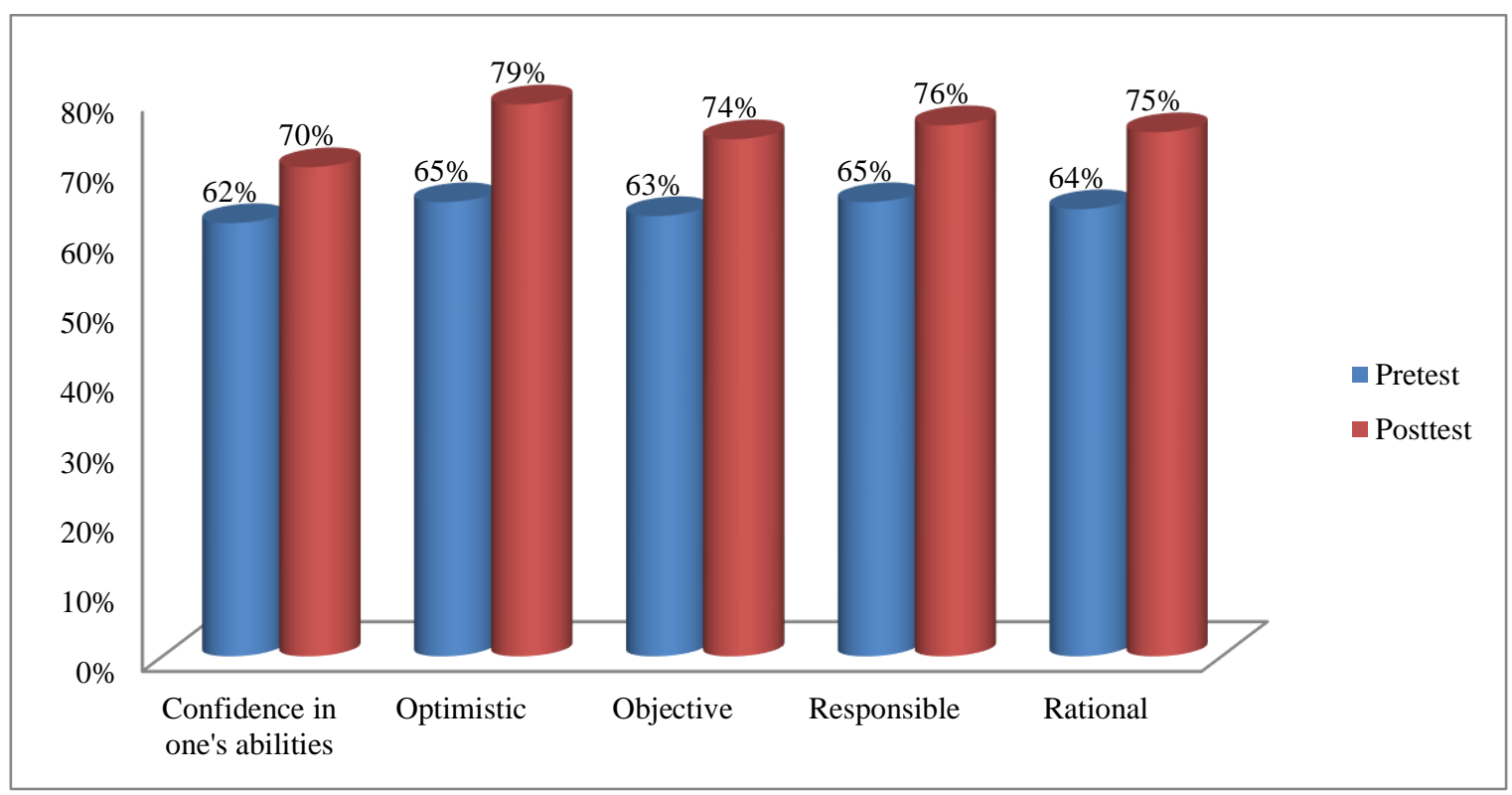

Figure 7. Percentage Self-Confidence in Senior High School 1 Negara Batin

Figure 5, Figure 6, and Figure 7 show an increase in each indicator in the three questionnaires. Before applying the conceptual change using the adobe Quran, students already had high self-regulation, self-efficacy, and self-confidence. So there was a very significant increase before and after applying conceptual change using the adobe Quran. It's in line with the research of Rahmawati and Partana in their research android use of media tends to be better than conventional learning (Rahmawati \& Partana, 2019). The student's success in studying is an indication that students understand every concept of lessons. If the student has high selfregulation, self-efficacy, and self-confidence, he has a high concept of understanding. So misconceptions could be reduced (Nastuti et al., 2018).

Based on the description above, the results are that conceptual changes using the adobe Quran can help reduce misconceptions and increase self-regulation, self-efficacy, and selfconfidence in biology class XI. The conceptual change model used is accompanied by the adobe Quran. The adobe Quran presents learning materials accompanied by learning videos and verses of the Quran with the interpretation of each verse besides that adobe Quran presents the latest info on reproductive system material. In carrying out the research, there are some obstacles in giving students the adobe Quran because the study is online. So the adobe Quran is given via screenshot through the Whatsapp Application.

\section{Conclusion}

The conclusions of this study are: (1) there was an effect of conceptual change using the adobe Quran on the reduction of misconceptions. This is because if the knowledge possessed by students conflicts with the new knowledge, it will cause a conflict that requires students to correct the false knowledge with existing evidence. (2) there is an effect of conceptual change using the adobe Quran on self-regulation, self-efficacy, and self-confidence. Because using conceptual change models using the adobe Quran can help students both maintain and enhance the emotional aspects they own. The process takes place in the 
composition of the opposition of confrontation with a demonstration of strategies, analogies, and opposing examples. This study concludes that the conceptual change model using the adobe Quran can reduce misconception and increase self-regulation, self-efficacy, and selfconfidence. The researcher suggests applying the conceptual change model using adobe Quran to other learning materials so that it can help in reducing misconceptions in other learning materials.

\section{References}

Anggoro, B. S., \& Haka, N. B. (2019). Pengaruh Model Pembelajaran Life Skill Terhadap Keterampilan Generik Biologi Ditinjau Dari Self Regulation. 7(1), 72-84.

Ardiyanti, Y., \& Rahmawati Utami, M. (2018). Identifikasi Miskonsepsi Siswa Pada Materi Sistem Reproduksi. Biosfer: Jurnal Biologi Dan Pendidikan Biologi, 2(2), 18-23. https://doi.org/10.23969/biosfer.v2i2.574

A’yun, Q. (2018). Analisis Miskonsepsi Siswa Menggunakan Tes Diagnostic Multiple Choice Berbantuan Cri (Certainty Of Response Index). 12(1), 10.

Bandura, Albert. (1986). Social Foundation On Thought And Action : A Social Cognitive Theory. New Jersey.

Berg. (1991). Miskonsepsi Fisika Dan Remediasi. Salatiga : Uksw.

Dini, M., Wijaya, T. T., \& Sugandi, A. I. (2018). Pengaruh Self Confidence Terhadap Kemampuan Pemahaman Matematik Siswa Smp. .. Issn, 3(1), 1-7.

Fitriani, N. (2015). Hubungan Antara Kemampuan Pemecahan Masalah Matematis Dengan Self Confidence Siswa Smp Yang Menggunakan Pendekatan Pendidikan Matematika Realistik. Euclid, 2(2), 341-351. https://doi.org/10.33603/e.v2i2.368

Frankel, R. Jack \& Norman, E. Wallen. (2009). Design And Evaluate Research In Education. New York.

Haka, N. B., Pratiwi, V. D., Anggoro, B. S., \& Hamid, A. (2020). Analisis Keterampilan Proses Sains Dan Self Regulation Biologi Kelas Xi: Pengaruh Model Auditory, Intellectually Dan Repatition (Audi-Ir). Journal Of Biology Education, 3(1), 16-31. https://doi.org/10.21043/jobe.v3i1.6922

Hidayatullah, Z., Jumadi, J., Nadhiroh, N., Kartika, E., Nuha, A. A., \& Erlangga, S. Y. (2020). Identifikasi Miskonsepsi Dan Konflik Kognitif Fisika: Kasus Terkait Perubahan Konseptual. Edusains, 12(1), 64-71. https://doi.org/10.15408/es.v12i1.13504

Irawati, R. K. (2019). Pengaruh Pemahaman Konsep Asam Basa Terhadap Konsep Hidrolisis Garam Mata Pelajaran Kimia Sma Kelas Xi. Thabiea: Journal Of Natural Science Teaching, 2(1), 1. https://doi.org/10.21043/thabiea.v2i1.4090

Khoiriyah, N. K. (2017). Profil Pereduksian Miskonsepsi Yang Dialami Oleh Siswa Setelah Penerapan Model Pembelajaran Conceptual Change Di Smpn 33 Surabaya Pada Topik Perubahan Materi. 05(03), 330-334.

Makhrus, Muh., Nur, M., \& Widodo, W. (2014). Model Perubahan Konseptual Dengan Pendekatan Konflik Kognitif (Mpk-Pkk). Jurnal Pijar Mipa, 9(1), 20-25. https://doi.org/10.29303/jpm.v9i1.39

Nastuti, R., Lelfita, L., \& Elbasthoh, E. (2018). Hubungan Self Efficasy Dan Motivasi Dengan Pemahaman Konsep Ipa Terpadu Siswa Kelas Viii Smp Pertiwi 2 Padang. Jurnal Ilmiah Universitas Batanghari Jambi, 18(3), 595. https://doi.org/10.33087/jiubj.v18i3.492

Oemar, Hamalik. (2012). Perencanaan Pengajaran Berdasarkan Pendekatan Sistem. Jakarta : Bumi Aksara.

Ormrod, Jeanne Ellis. (2009). Psikologi Pendidikan. Jakarta : Erlangga. 
Pebriyanti, D., \& Sahidu, H. (2015). Efektifitas Model Pembelajaran Perubahan Konseptual Untuk Mengatasi Miskonsepsi Fisika Pada Siswa Kelas X Sman 1 Praya Barat Tahun Pelajaran 2012/2013. 1, 5. http://dx.doi.org/10.29303/jpft.v1i2.241

Rachmawati, T. N., \& Supardi, Z. A. I. (2021). Analisis Model Conceptual Change Dengan Pendekatan Konflik Kognitif Untuk Mengurangi Miskonsepsi Fisika Dengan Metode Library Research. Pendipa Journal Of Science Education, 5(2), 133-142. https://doi.org/10.33369/pendipa.5.2.133-142

Rahmawati, T., \& Partana, C. F. (2019). Pengaruh Media Pembelajaran Asam Basa Berbasis Android Terhadap Efikasi Diri Peserta Didik. Jtk (Jurnal Tadris Kimiya), 4(2), 147156. https://doi.org/10.15575/jtk.v4i2.5022

Ramadhan, Y., Nisa, K. R., \& Sunarwin, S. (2020). Analysis Of Students Misconception Using Certainly Of Response Index (Cri) In The Periodic System Of Elements Concept. Educhemia (Jurnal Kimia Dan Pendidikan), 5(2), 210. https://doi.org/10.30870/educhemia.v5i2.8285

Ramadhani, R. (2016). Identifikasi Miskonsepsi Siswa Pada Konsep Sistem Reproduksi Manusia Kelas Xi Ipa Sma Unggul Ali Hasjmy Kabupaten Aceh Besar. 1(1), 1-9.

Rapih, S., \& Sutaryanto, S. (2017). Pengaruh Model Pembelajaran Perubahan Konseptual (Mppk) Terhadap Hasil Belajar Ips Dan Sikap Multikultural Siswa Sekolah Dasar Berlatar Belakang Monokultur. Premiere Educandum : Jurnal Pendidikan Dasar Dan Pembelajaran, 7(02), 180-188. https://doi.org/10.25273/pe.v7i2.1599

Ridwan. (2014). Dasar-Dasar Statistika. Bandung : Alfabeta.

Rizaldi, D. R., Makhrus, Muh., \& Doyan, A. (2019). Analisis Tingkat Kemampuan Berpikir Kritis Dengan Model Perubahan Konseptual Ditinjau Dari Gaya Belajar Siswa. Jurnal Pendidikan Fisika Dan Teknologi, 5(1), 74. https://doi.org/10.29303/jpft.v5i1.794

Robert, J Marzano. (1994). Assessing Students Outcomes : Performance Assessment Using The Dimensions Of Learning Model. Virginia : Association For Supervition Curriculum Development.

Sagala, Syaiful. (2012). Konsep Dan Makna Pembelajaran. Bandung : Alfabeta.

Santyasa, I Wayan. (2007). Landasan Konseptual Media Pembelajaran. Prosiding Workshop Media Pembelajaran. Bali : Universitas Pendidikan Ganesha.

Sumaryanto, T., \& Lestari, W. (2015). Pengembangan Instrumen Penilaian Aspek Psikomotor Pembelajaran Ipa Materi Tumbuhan Hijau Kelas V Berbasis Kompetensi Pendekatan Sea Berwawasan Konservasi. 4(2), 10.

Suparno, Paul. (2005). Miskonsepsi Dan Perubahan Konsep Dalam Pendidikan Fisika Cetakan Ke-1. Jakarta : Pt. Grasindo.

Syam, A. (2017). Pengaruh Kepercayaan Diri (Self Confidence) Berbasis Kaderisasi Imm Terhadap Prestasi Belajar Mahasiswa (Studi Kasus Di Program Studi Pendidikan Biologi Fakultas Keguruan Dan Ilmu Pendidikan Universitas Muhammadiyah Parepare)...., 5(1), 87-102. https://doi.org/10.24252/jb.v5i1.3448

Utami, S., Rufaidah, A., \& Nisa, A. (2020). Kontribusi Self-Efficacy Terhadap Stres Akademik Mahasiswa Selama Pandemi Covid-19 Periode April-Mei 2020. Teraputik Jurnal Bimbingan Dan Konseling, 4(1), 20-27. https://doi.org/10.26539/teraputik.41294 